\title{
Design of a Street-Style Motorcycle Concept
}

Tashko Rizov

Assistant Professor

University of "Ss. Cyril and Methodius" Faculty of Mechanical Engineering - Skopje

N. Macedonia

\section{Risto Tashevski}

Professor

University of "Ss. Cyril and Methodius" Faculty of Mechanical Engineering - Skopje

N. Macedonia

Hristijan Najdeski

PhD student

University of "Ss. Cyril and Methodius" Faculty of Mechanical Engineering - Skopje

N. Macedonia

This paper presents the design process of a motorcycle with a street-style chassis. Motorcycle design can be described as activities that define the appearance, function and engineering of motorcycles. The design process presented is consisted of several steps like analysis of the existing motorcycles in the category, analysis of the engineering design of the structures, ergonomics and design of the riding position, creating a $3 D$ model and rendering. The main goal of the paper is to design a new chassis of a motorcycle in the street-style in compliance with the ergonomic and engineering requests. This paper aims to discuss the specific features, benefits, and precautions when using design optimization to develop a specific project. After selecting the optimized design of the product, a 3D model has been created to visualize the final result. The $3 D$ model presents the selected geometry and materials selection. Using photo-realistic rendering the final model has been presented to provide the decision makers with the ability to visualize the product in order to analyze if the design is satisfactory.

Keywords: motorcycle; futuristic design; ergonomics; rendering; $3 D$ model.

\section{INTRODUCTION}

Street or naked motorcycles are different and adaptable types of motorcycles that can be used for different types of rides. In general, they are driven on smooth surfaces due to their slick tires. They are easily detectable by the position of the driver, because the handles of the steering wheel are on a higher position. This is also the same for the leg support of the driver (Fig.1).

This results in a driver posture that is not lowered like when driving a sport motorcycle, or thrown back like in the cruiser motorcycles [1]. Because of their flexibility, the relatively low price and the engine size of $125 \mathrm{cc}$ to $1000 \mathrm{cc}$ they are both good for beginners and for experienced drivers.

Different modifications of the street motorcycles exist, like:

- Monster - where the position of the driver is the same like in street style but the engine size and power of the motorcycle is bigger.

- Roadster - are the motorcycles that have a standard street chassis but with more additional equipment like: bigger wind shield, additional storage compartments, fog lights etc.

\section{BACKGROUND}

When thinking of a street style motorcycle the first thought in mind is the aggressive look, the open view of the engine, the open view of the chain and support (Fig.

Received: June 2018, Accepted: December 2018. Correspondence to: Tashko Rizov, Assistant Professor, University of "Ss. Cyril and Methodius" in Skopje, Faculty of Mechanical Engineering, N. Macedonia E-mail: tashko.rizov@mf.edu.mk

doi: doi:10.5937/fmet1902258R

(C) Faculty of Mechanical Engineering, Belgrade. All rights reserved 2a). The engine size and power vary from low to high [1]. Most common size of the engine for these motorcycles is 500 or 600 cubic centimeters (cc) (Fig 2b). The main characteristic of the street style motorcycles is that transfer of torque in lower gear of the transmission system is lower in order to avoid aggressive and uncontrolled starts regardless of the engine size and power [2].

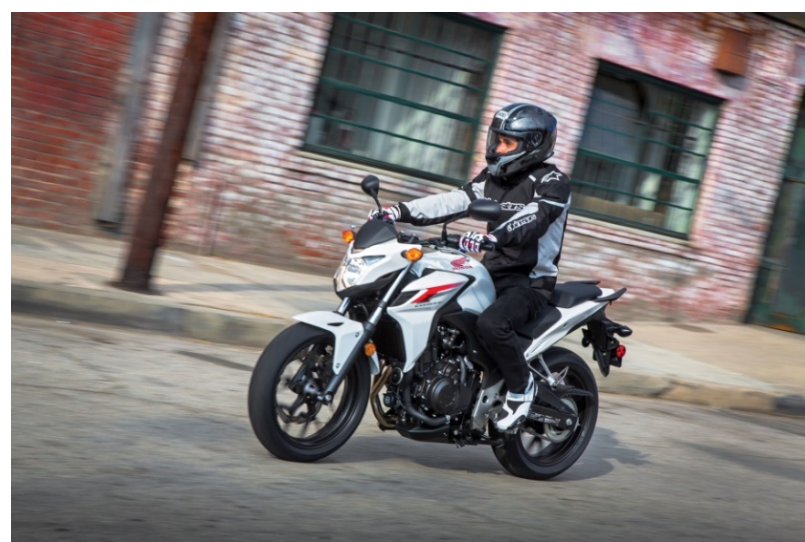

Figure 1. 2014 Honda CB500F Street motorcycle (Source: Honda)

Examples of motorcycles with engine capacity in the mid-size range are Yamaha Xj6, Honda CB500F, Suzuki SV650, Triumph Street Triple etc. This motorcycles have a higher position of the handles of the steering column and with that the driver has to sit in an upright posture [3]. This increases the braking efficiency. Also, when ride in a conjunct traffic the driver field of view is above the cars making it much more efficient and safe [4].

The position of the feet is lower which gives advantage in the often start and stop type of riding in urban 
areas giving a much greater control to the driver over the motorcycle (Fig.3).

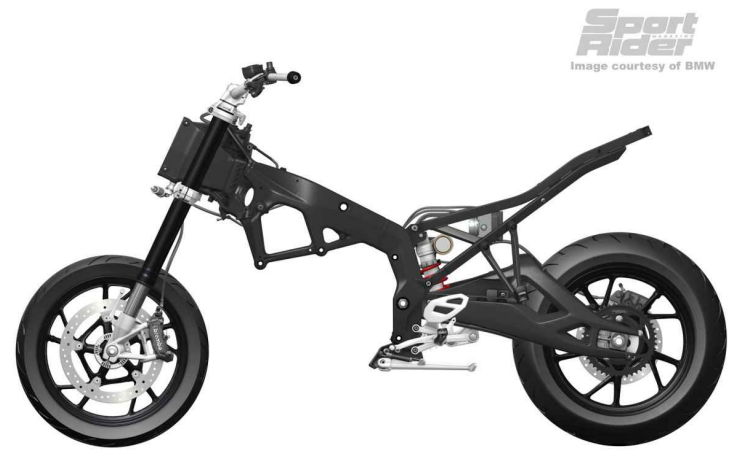

Figure 2a. Chassis of BMWXR 1000. (Source BMW)

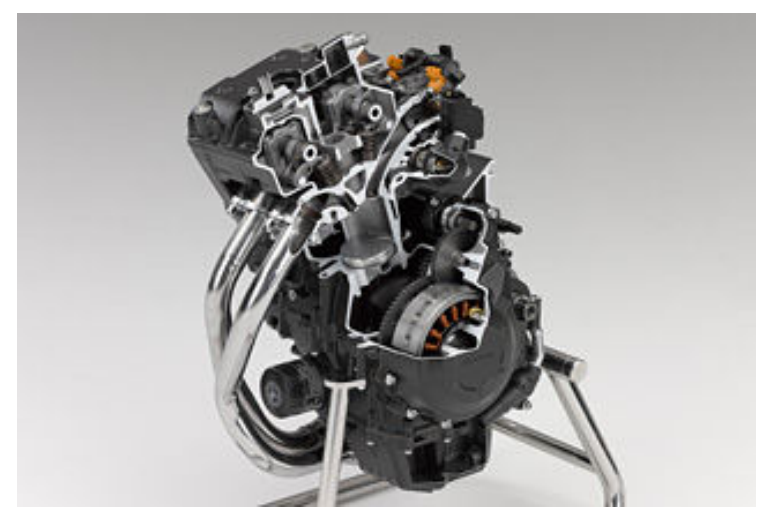

Figure 2b. Parallel twin engine of Honda 500cc. (Source Honda)
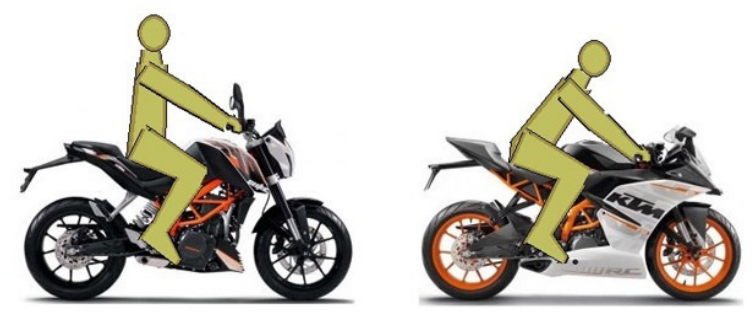

Figure 3. The rider's position in a street style motorcycle (on the left) and in a sport style motorcycle (on the right).

For the front suspension system the usual construction is to use telescope dampers. The function of the telescope dampers is to reduce the force that is applied when decreasing the speed, absorbing the force and distributing it to the road (Fig. 4). As a result of that the telescope are contracted and the front end of the motorcycle is lowered [5]. The main downside of this motion is that it decreases the control of the motorcycle.

Honda in the 70-ies designed the anti-drive system for motorcycles, but it showed poor efficiency on uneven surfaces. Nevertheless, in the coming years with numerous research this system was further developed and made much more efficient.

The rear dumpers have been significantly changed in the last 50 years and almost different companies producing motorcycles have own approach in designing the suspension system.

Yamaha uses dampers their designed in the 80-ies and they are continuously improving the design (Fig. 5a). BMW is one of the companies that has significantly improved the rear suspension system (Fig. 5b). Similar to Yamaha they use a mono-shock absorber but with that modification that the absorber is placed on the side and it is connected to the transmission [3].

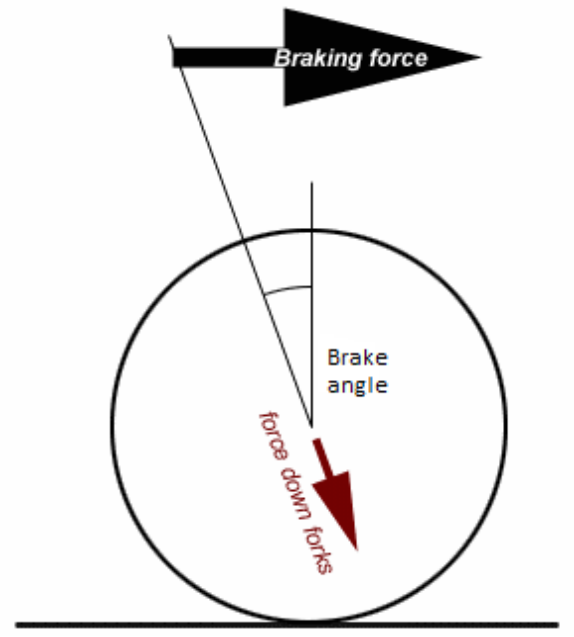

Figure 4. Forces while braking in motorcycles.

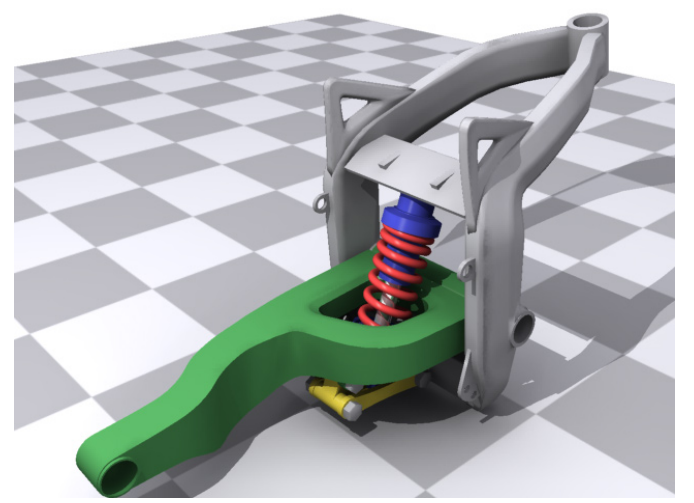

Figure 5a. Engineering design concept of the rear monoshock absorber subassembly by Yamaha.

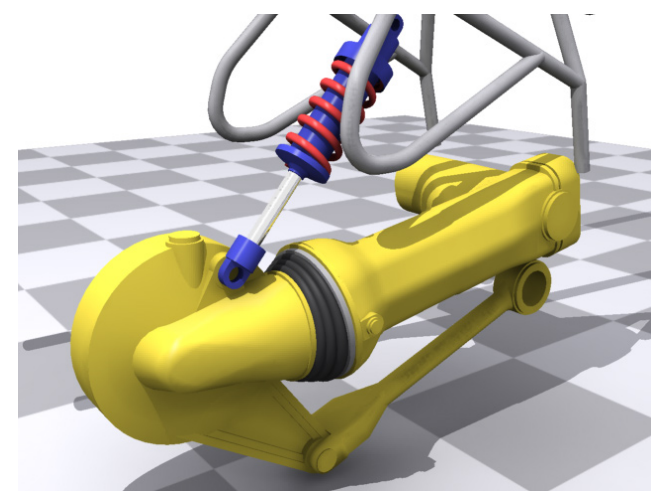

Figure 5b. Engineering design concept of the rear monoshock absorber subassembly by BMW.

\section{DESIGN OF A STREET STYLE MOTORCYCLE}

As a reference for the ergonomics of the motorcycle the model of Honda's CB500F motorcycle was used (Fig. $6)$. The position of the handle bars high enough so the rider can curl the hands if needed. The leg supports are low enough to provide a good control in continuous start and stop ride style, which shortens the movement of the legs.

The front suspension system uses a telescopic damper, where the rear suspension is according to the de- 
sign principle of Yamaha. Main part of the motorcycles of this category is the front mask that is the part where the front lights are located with or without the tur lights (Fig. 7).

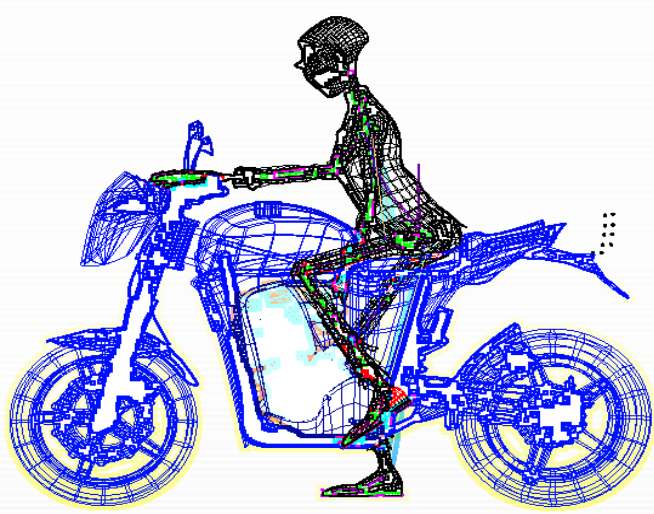

Figure 6. Ergonomics of Honda CB500F.

The goal of the design is to keep the aerodynamics of the motorcycle so that is why the shape resembles a bird with sharp and curved shapes.

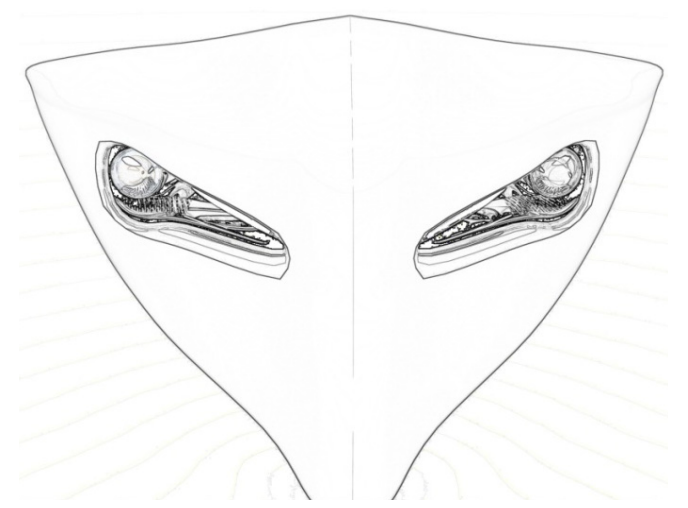

Figure 7. Inspiration of the design of the front mask from birds.

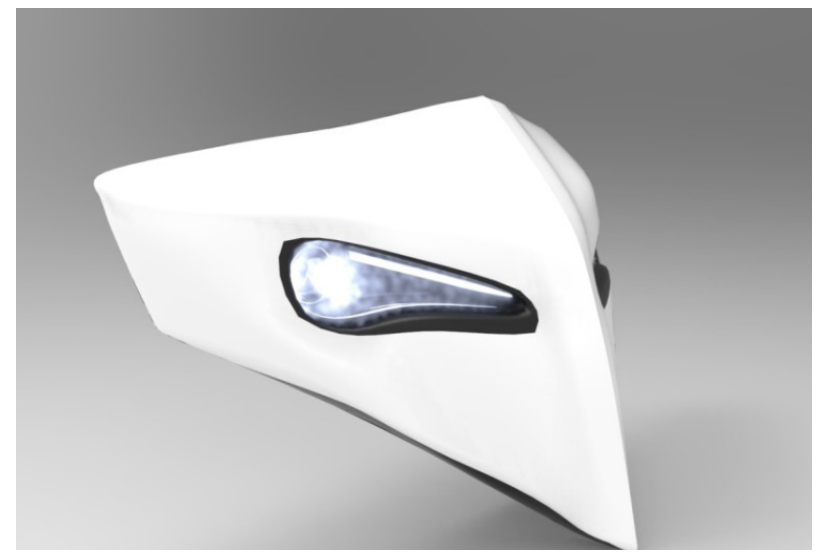

Figure 8. Design of the front mask with lights

The front lights are consisted of day lights in LED technology that provide intense light, enough to mark the position of the motorcycle in bright daylight (Fig. 8). The night lights are of xenon technology with eno-ugh intensity to provide visibility of the area in front of the driver but without blinding the other participants in the traffic.

The rear lights are consisted of two vertical LED tubes and when brake is applied a group of 3 by 4 LED lights are turned on. The front turn lights are integrated into the side mirrors and they consist of 4 LED lights placed on each side mirror. The rear turn lights are placed on the additional bracket that is used for placing the registration plate and they consist of 2 LED lights (Fig. 9).
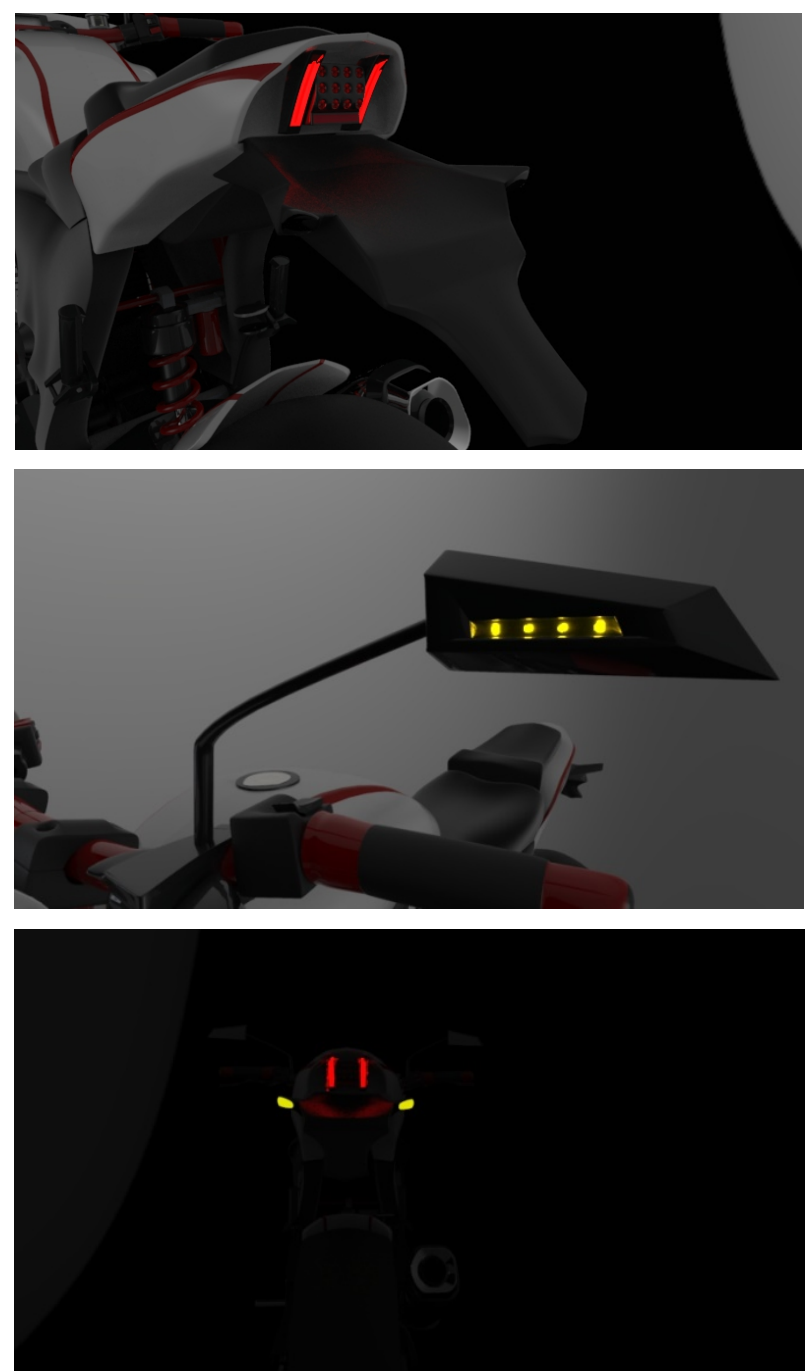

Figure 9. Design of the rear lights, front and back turn lights.

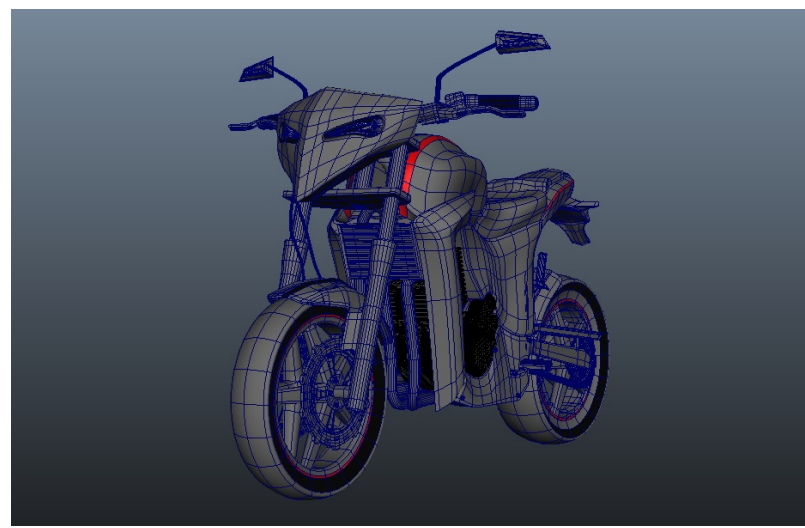

Figure 10. Modelling of the motorcycle in Autodesk Maya.

For the creation of the 3D model the software package Autodesk Maya was used. The polygonal modeling was used to easier manipulate and get smooth surfaces in the end of modeling (Fig. 10). In order to get a correct symmetry of the model, only one side of the motorcycle was modeled and then using the duplicate special option the mirror of the final object was created. 
For visualization, the colors were added to the model in order to notice the different parts. This is also important for the rendering process later [6]. After completing the modeling the model was exported as FBX object.

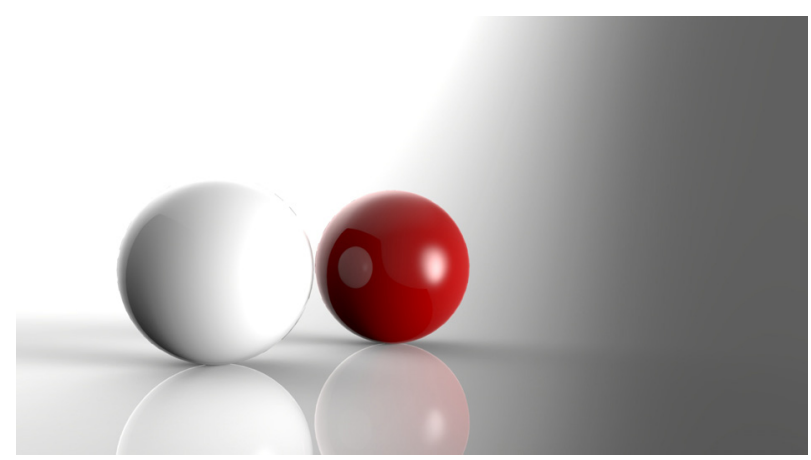

Figure 11. Spheres for test rendering in Keyshot 5.0.

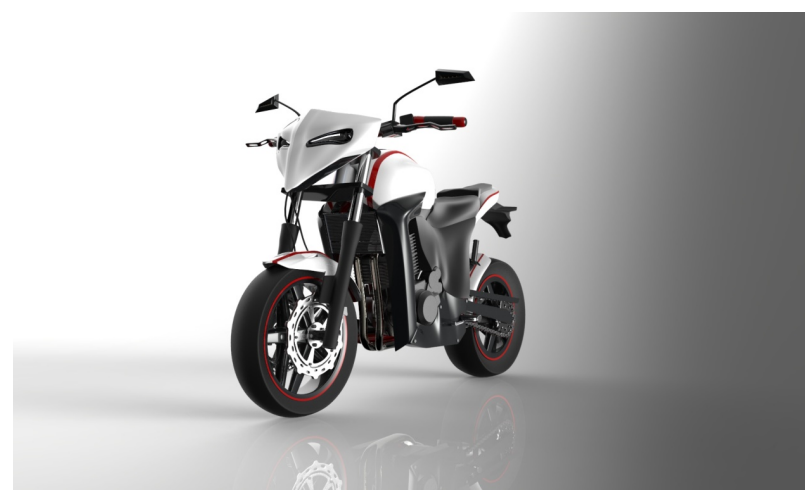

Figure 12. Render of front view.

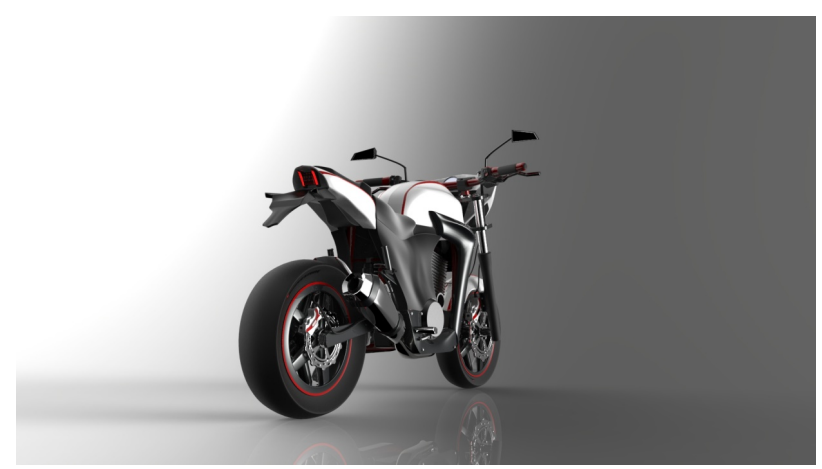

Figure 13. Render of rear view.

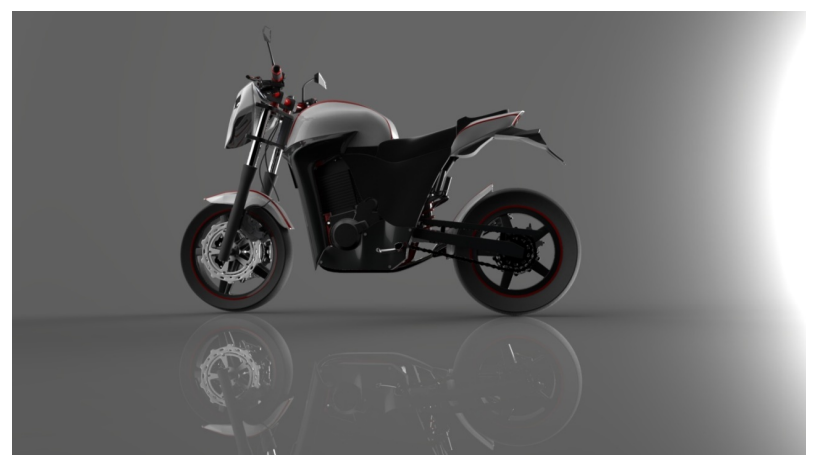

Figure 14. Render of side view.

For rendering the software package Keyshot 5.0 was used. This software package provides renderings with real photo like quality. The software was also used to add an appropriate scene. In this case, as scene was selected a HDR studio photo that was light enough in order to make the appearance of the colors vivid enough to resemble reality.

The scene photo LightTentBlackFloor2k.hdr was adjusted to a1.5 contrast using two light sources and a dark floor. To create a photo like rendering the setting of the lens was set for focal length $35 \mathrm{~mm}$, field of view $54.4 \mathrm{~mm}$ and f-stop 1 .

The test render was created using two spheres in white and red color in order to get a high contrast (Fig. 11).

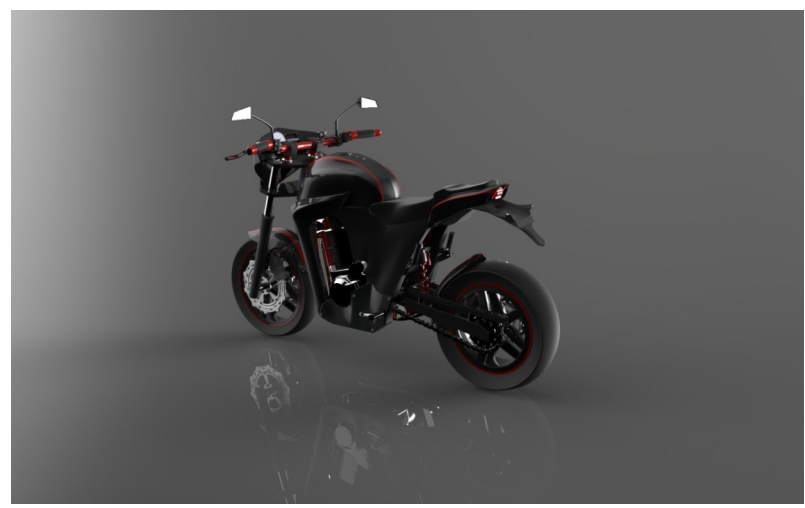

Figure 15. Render of rear side view.

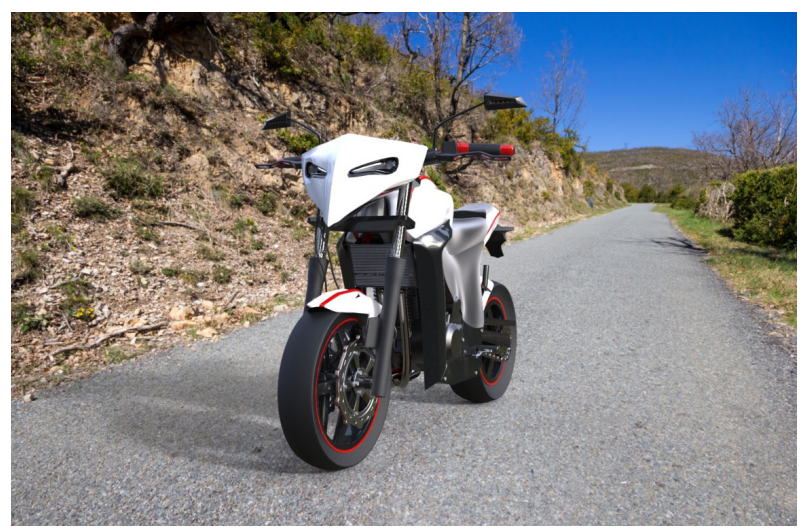

Figure 16. Render of front view in scene.

Because the colors of the spheres are well defined and the shadows and shine are appropriate, the rendering settings ca be applied to the 3D model [6]. In the next step the materials and the textures are set to the 3D model of the motorcycle. The result render is presented in figure 12 to 17 .

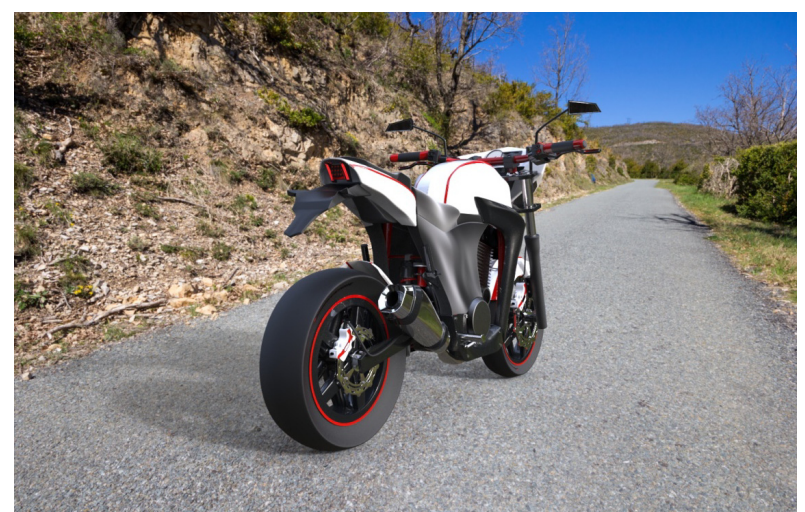

Figure 17. Render of rear view in scene. 


\section{CONCLUSION}

The street style motorcycles are vehicles for the urban area. The position of the driver enables the rider to have a better view of the surrounding and a better comfort while riding. From the beginning this type of motorcycles is one of the best-selling motorcycles. Their price, design and efficiency in riding in traffic makes them attractive for every motorcycle lover. The street style motorcycles can move much easier in urban areas and they provide a unique experience of the environment while riding. Changing their tires easily makes them a good ride for the terrain too.

The street style motorcycles are attractive for the beginners as well as for the experienced drivers. The companies producing motorcycles invest a lot in the segment offering a variety of models with different design, different engine capacity in order to appeal to bigger audience.

\section{REFERENCES}

[1] Damage, M. O. T., Repairs, F., Low, I. N., Or, S., and Falls, S.: Motorcycle design guide, Springer, No. 9, 2009.

[2] Design, C.: A Freshman Seminar: The Art and Science of Motorcycle Design, Princeton, USA, 2011.

[3] M. I. N. Ma'arof et al: The Motorcycle Design Parameter Database (MDPD) for Different Motorcycle Models, Procedia Manuf., Vol. 3, no. December, pp. 2581-2588, 2015.

[4] Chandra, S.: Introduction: Motorcycle and the Semantics of Design. In: Aesthetics: Quantification and Deconstruction. Design Science and Innovation., Springer, Singapore, 2003.
[5] Camargo, F. V., Fragassa, C., Pavlovic, A., and Martignani, M.: Analysis of the Suspension Design Evolution in Solar Cars, FME Transactions, Vol. 45, pp. 394-404, Serbia, 2017.

[6] Ristevski, S., Tashevski, R., Rizov, T.: Concept Design of a Sports Coupe with Ergonomic Analysis and Photorealistic Rendering, FME Transactions, vol. 45 , no. 2 , pp. $288-293$.

\section{ДИЗАЈН КОНЦЕПТА МОТОЦИКЛА У ДРУМСКОМ СТИЛУ}

\section{Т. Ризов, Р. Ташевски, Х. Најдески}

Овај рад представља процес дизајнирања мотоцикла са друмском шасијом. Дизајн мотоцикла може се описати као активности које одређују изглед, функцију и инжењеринг мотоцикала. Процес дизајнирања представљен је у неколико корака као што су анализа постојећих мотоцикала у категорији, анализа инжењерског дизајна конструкције, ергономија и дизајн положаја возача, креирање 3Д модела и рендеринг. Главни циљ рада је да се дизајнира нова шасија мотоцикла у друмском стилу у складу са ергономским и инжењерским захтевима. Овај рад има за циљ да дискутује о специфичним карактеристикама, предностима и мерама предострожности када се користи оптимизација дизајна за развој одређеног пројекта. Након одабира оптимизованог дизајна производа, креиран је ЗД модел за визуализацију коначног резултата. 3Д модел представља одабрану геометрију и одабрани материјал. Употребом фото-реалистичног приказа представљен је коначни модел како би се доносиоцима одлука пружила могућност да визуализују производ како би анализирали да ли је дизајн задовољавајући. 